ALIME BAYINDIR $(*)\left({ }^{\circ}\right)$ - ALİ KEMAL BİRGÜCÜ $(* *)$

\title{
EFFECT OF TEMPERATURE ON LIFE HISTORY OF CHRYSOMPHALUS DICTYOSPERMI (MORGAN) (HEMIPTERA DIASPIDIDAE) $\left(^{1}\right)$
}

\author{
$(*)\left({ }^{\circ}\right)$ Organic Farming Business Management Department, School of Applied Sciences, Pamukkale University, 20600, \\ Denizli-Turkey \\ (**) Plant Protection Department of Agricultural Faculty, Süleyman Demirel University, 32260, Isparta-Turkey \\ $(*)\left({ }^{\circ}\right)$ Corresponding author: abayindir@pau.edu.tr
}

Bayındır A., Birgücü A.K. - Effect of temperature on life history of Chrysomphalus dictyospermi (Morgan) (Hemiptera Diaspididae).

This study documented the life table parameters of Chrysomphalus dictyospermi (Morgan) (Hemiptera: Diaspididae) reared on pumpkins at three different constant temperatures $\left(22.5,25,27.5\right.$, and $\left.30^{\circ} \mathrm{C} \pm 1\right)$, constant relative humidity $(65 \pm 5 \%)$ and long photoperiod $(16: 8 \mathrm{~L}: \mathrm{D})$. The intrinsic rate of increase $\left(r_{m}\right)$ was 0.03 female/female/day at $22.5^{\circ} \mathrm{C}, 0.05$ females/female/day at $25^{\circ} \mathrm{C}, 0.04$ females/female/day at $27.5^{\circ} \mathrm{C}$, and 0.06 females/female/day at $30^{\circ} \mathrm{C}$. The reproductive rate $\left(R_{o}\right)$ was $22.89,50.96,24.79$, and 70.58 females/female at $22.5,25,27.5$, and $30^{\circ} \mathrm{C}$, respectively. The generation time $\left(T_{o}\right)$ was found $102.17,67.04,66.21$, and 68.48 days at $22.5,25,27.5$, and $30^{\circ} \mathrm{C}$, respectively. In addition the gross reproduction rate $(G R R)$ was calculated as $32.76,66.96,33.07$, and 88.60 females/female, the doubling time $\left(T_{2}\right)$ was $22.62,11.82,14.29$, and 11.15 days, and the finite rate of increase $(\lambda)$ was $1.03,1.06,1.04$, and 1.06 females/female at $22.5,25,27.5$, and $30^{\circ} \mathrm{C}$, respectively.

KEY WoRDS: Chrysomphalus dictyospermi, life table, pumpkin, temperature.

\section{INTRODUCTION}

The scale insect family Diaspididae (Hemiptera: Coccoidea) includes a number of important pests of wild and cultivated plants (ALFORD, 2007). Chrysomphalus Ashmead, 1880, includes 17 species worldwide, five of which are found in Europe: C. aonidum (Linnaeus), C. bifasciculatus Ferris, $C$. dictyospermi (Morgan), $C$. diversicolor Green, and $C$. pinnulifer (Maskell) (BEN-Dov, 2012). C. dictyospermi is native to southern China and distributed widely in the tropical and subtropical areas (LONGO et al., 1995; GILL, 1997). Host list includes 234 species, 226 genera and 95 families. Principal hosts are Citrus, Dracaena and palms (USDA, 2014). In the Palaearctic region (DANZIG \& Pellizzari, 1998), South Pacific (Williams \& Watson, 1988), Western Mediterranean and Florida (CHUA \& WoOD, 1990; GILL, 1997). C. dictyospermi is an important pest of citrus. It is a pest of olive trees in Italy, Spain and Turkey (ARGYRIOU, 1990). It occurs primarily on leaves, sometimes on fruit and on branches. Toxic substances secreted during feeding leads to chlorosis on leaves, and in severe cases leading to desiccation, and even death of the branches (GILL, 1997; FOLDI, 2001). The female lives for several months and produces 1-200 eggs (ChKHAIDZE \& YASNOSH, 2001). C. dictyospermi has 3-6 generations annually in Turkey; 3-4 generations in California and 2 generations in Egypt (GILL, 1997; FOLDI, 2001). Crawler development is completed in 71 days at $25^{\circ} \mathrm{C}$ and 91 days at $18^{\circ} \mathrm{C}$ (CABIDO-GARCIA, 1949). Temperature is an abiotic factor with important effects on population dynamics, ecology and biology of pests and natural enemies. This study reports on the

\footnotetext{
${ }^{1}$ Original scientific contribution presented and discussed at XIV International Symposium on Scale Insect Studies, Catania-Italy, 13-16 June 2016.
}

biological parameters and reproduction values of $C$. dictyospermi when reared on pumpkin at four different constant temperatures ranging from 22.5 to $30^{\circ} \mathrm{C}$ at $2.5^{\circ} \mathrm{C}$ increments. Thus, trying to simulate how population levels of the pest will be affected against seasonal and global temperature changes.

\section{MATERIALS AND METHODS}

\section{REARING OF CHRYSOMPHALUS DICTYOSPERMI}

Twig parts, leaves and fruits infested with $C$. dictyospermi were collected from citrus orchards in Antalya in 2014. These infested plant parts were located on uninfested pumpkins in a climate room with the $25 \pm 1^{\circ} \mathrm{C}$ temperature, $60 \pm 5 \%$ relative humidity and $16: 8 \mathrm{~h}$. (L:D) photoperiod conditions. The pumpkin, Cucurbita maxima Duchesne (Cucurbitaceae), was used as host for $C$. dictyospermi. Newly hatched crawlers were transferred to pumpkin fruits and later, the infested citrus twig parts, leaves and fruits were removed. When these crawlers settled on pumpkin reached to oviposition period of adult stage, clean pumpkin fruits were added to the production chains of the scale pests. In this way, the increase and continuity of the scale pest production were ensured.

\section{EXPERIMENTAL DESIGN}

Newly infested pumpkins with crawlers were used in the experiments. After the crawlers had settled on the pumpkins, a $2 \times 2 \mathrm{~cm}$ area was marked on each pumpkin using a sticky material (Tanglefoot ${ }^{\circledR}$ trademark). The cohorts isolated within the area were considered individual replicates, and they were examined daily for development and survival. The time of preoviposition, oviposition and 
postoviposition, the sex ratio of adults, the settlement rate of crawlers were recorded daily. To determine fecundity, all but two females were removed from each marked area, and the number of crawlers emerged from the two females were recorded daily.

The experiments were performed at four constant temperatures $\left(22.5,25,27.5\right.$, and $\left.30 \pm 1^{\circ} \mathrm{C}\right), 60 \pm 5 \% \mathrm{RH}$, and long photoperiod (16:8 L:D) in climate chambers. The experiments at $22.5,25,27.5$, and $30 \pm 1^{\circ} \mathrm{C}$ were conducted with $73,68,60$, and 59 replicates, respectively.

\section{LIFE TABLES}

Data on age-specific survival rate $\left(1_{\mathrm{x}}\right)$ and age-specific fecundity $\left(\mathrm{m}_{\mathrm{x}}\right)$ obtained in the experiment were used to conduct life table analysis. Life table parameters were estimated with Euler-Lotka equation (BIRCH, 1948).

The life table parameters estimated in this study:

Net reproductive rate (Females/female),

$$
R_{0}=\sum l_{x} \cdot m_{x}
$$

(BIRCH, 1948), and Intrinsic rate of increase (females/ female/day) $\left(r_{m}\right)$ were determined by solving the equation

$$
\sum e^{\left(-r_{m} \cdot x\right)} \cdot l_{x} \cdot m_{x}=1
$$

(BIRCH, 1948). Also, Mean generation time (Day),

$$
G R R=\sum m_{x}
$$

(BIRCH, 1948), Gross reproduction rate (crawlers/female),

$$
T_{0}=\frac{\ln \cdot R_{0}}{r_{m}}
$$

(BIRCH, 1948), Finite rate of increase (crawlers/female/day), $\lambda=\mathrm{e}^{r_{m}}$ (BIRCH, 1948), and Doubling time (Day),

$$
T_{2}=\frac{\ln 2}{r_{m}}
$$

(KAIRO and MURPHY, 1995) were calculated.

The $r_{m}$ rates obtained from the lifetable parameters, pseudo$r_{m j}$ were obtained as the number of replicates for different temperatures by using Jack-knife method (MEYER et al., 1986; ÖZGÖKÇE and ATLIHAN, 2005). Statistical differences were determined with One Way ANOVA analysis between the different temperatures. The statistical data analyses were done by using SPSS ${ }^{\circledR}$ Statistics (Version 20.0, August 2011, SPSS Inc., Chicago, IL, USA.) software package.

The linear model presented in CAMPBELL et al., (1974) was used to calculate developmental zero $(C$, the lower developmental threshold), and thermal constant (K, the total effective temperature required to complete a generation) of C. dictyospermi. In this model $\left(\mathrm{d}_{(\mathrm{T})}=\mathrm{a}+\mathrm{bT}\right), \mathrm{T}$ is temperature $\left({ }^{\circ} \mathrm{C}\right), \mathrm{d}_{(\mathrm{T})}$ is developmental rate (proportion of developmental time, $1 / \mathrm{t}$ ), and the parameters $\mathrm{a}$, and $\mathrm{b}$ are constants. The developmental zero $\left({ }^{\circ} \mathrm{C}\right)$ are calculated according to the formula $\mathrm{C}=-\mathrm{a} / \mathrm{b}$ and thermal constant (degree days) are calculated according to formula $\mathrm{K}=1 / \mathrm{b}$.

\section{RESULTS AND DISCUSSION}

Development periods of growing populations of $C$. dictyospermi were different from each other under different constant temperature conditions. The longest total nymphal development time was 82.00 days at $22.5^{\circ} \mathrm{C}$, and the shortest was 52.00 days at $27.5^{\circ} \mathrm{C}$. Developmental period decreased until $27.5^{\circ} \mathrm{C}$ depending on the temperature rise and it started to rise again at $30^{\circ} \mathrm{C}$. The shortest preoviposition period occurred at 0.00 days and the longest oviposition period was 49.89 days at $30^{\circ} \mathrm{C}$. The longest postoviposition time was 26.09 days at $27.5^{\circ} \mathrm{C}$. It was determined that the longest generation time was 84.31 days at $22.5^{\circ} \mathrm{C}$. The longest adult life time was 65.96 days at $27.5^{\circ} \mathrm{C}$ and the shortest time was 50.23 days at $25^{\circ} \mathrm{C}$. The longest total life time was 101.91 days at $22.5^{\circ} \mathrm{C}$. The highest daily number of crawlers was 3.45 crawlers at $25^{\circ} \mathrm{C}$ and 201.38 crawlers at $30^{\circ} \mathrm{C}$ (Table 1).

The linear equation $\mathrm{d}_{(\mathrm{T})}=0.0014 \mathrm{~T}-0.0185\left(\mathrm{R}^{2}=0.8251\right)$ sufficiently described the relationship between the temperature and developmental rate of $C$. dictyospermi (Fig. I). The developmental zero (C) was estimated as $13.21^{\circ} \mathrm{C}$ and the total effective temperature required to

Table 1 - Development times (Day) and fecundity rates of Chrysomphalus dictyospermi at different temperatures*.

\begin{tabular}{lcccccccc}
\hline \hline & $\mathrm{n}$ & $22.5^{\circ} \mathrm{C}$ & $\mathrm{n}$ & $25^{\circ} \mathrm{C}$ & $\mathrm{n}$ & $27.5^{\circ} \mathrm{C}$ & $\mathrm{n}$ & $30^{\circ} \mathrm{C}$ \\
\hline The first nymphal stage & 51 & 32.00 & 52 & 22.00 & 45 & 22.00 & 47 & 24.00 \\
The second nymphal stage & 51 & 50.00 & 52 & 32.00 & 45 & 30.00 & 47 & 32.00 \\
Total nymphal development & 51 & 82.00 & 52 & 54.00 & 45 & 52.00 & 47 & 56.00 \\
\hline Preoviposition & 51 & $1.31 \pm 0.24 \mathrm{a}$ & 52 & $0.12 \pm 0.05 \mathrm{~b}$ & 45 & $1.80 \pm 0.40 \mathrm{a}$ & 47 & $0.00 \pm 0.00 \mathrm{~b}$ \\
Oviposition & 51 & $49.47 \pm 1.16 \mathrm{a}$ & 52 & $41.31 \pm 1.03 \mathrm{~b}$ & 45 & $38.07 \pm 1.34 \mathrm{~b}$ & 47 & $49.89 \pm 2.36 \mathrm{a}$ \\
Postoviposition & 51 & $9.22 \pm 1.11 \mathrm{~b}$ & 52 & $8.01 \pm 0.87 \mathrm{~b}$ & 45 & $26.09 \pm 1.26 \mathrm{a}$ & 47 & $13.11 \pm 2.36 \mathrm{~b}$ \\
Generation & 51 & $84.31 \pm 0.24 \mathrm{a}$ & 52 & $55.12 \pm 0.05 \mathrm{c}$ & 45 & $52.80 \pm 0.40 \mathrm{~d}$ & 47 & $57.00 \pm 0.00 \mathrm{~b}$ \\
Adult life time & 51 & $60.00 \pm 0.00 \mathrm{c}$ & 52 & $50.23 \pm 0.86 \mathrm{~d}$ & 45 & $65.96 \pm 0.03 \mathrm{a}$ & 47 & $63.00 \pm 0.00 \mathrm{~b}$ \\
Total life time & 73 & $101.92 \pm 7.19 \mathrm{a}$ & 68 & $82.29 \pm 4.87 \mathrm{a}$ & 60 & $89.47 \pm 5.97 \mathrm{a}$ & 59 & $96.22 \pm 5.92 \mathrm{a}$ \\
Daily number of crawlers & 51 & $0.88 \pm 0.62 \mathrm{~b}$ & 52 & $3.45 \pm 0.17 \mathrm{a}$ & 45 & $0.75 \pm 0.04 \mathrm{~b}$ & 47 & $3.20 \pm 0.19 \mathrm{a}$ \\
Total number of crawlers & 51 & $52.84 \pm 3.71 \mathrm{c}$ & 52 & $170.44 \pm 7.95 \mathrm{~b}$ & 45 & $49.27 \pm 2.86 \mathrm{c}$ & 47 & $201.38 \pm 11.89 \mathrm{a}$ \\
\hline
\end{tabular}

* Means ( \pm Standard errors) followed by different letters within columns are significantly different (Tukey's $\mathrm{HSD} ; \mathrm{P}<0.05 ; \mathrm{F}_{\text {Preoviposition }}=15.574, \mathrm{df}=3.191, \mathrm{P}=0.00 ; \mathrm{F}_{\text {Oviposition }}=14.573 ; \mathrm{df}=3.191 ; \mathrm{P}=0.00$; $\mathrm{F}_{\text {Postoviposition }}=28.778, \mathrm{df}=3.191, \mathrm{P}=0.00 ; \mathrm{F}_{\text {Generation }}=4518.658, \mathrm{df}=3.191, \mathrm{P}=0.00 ; \mathrm{F}_{\text {Adult life }}=238.142, \mathrm{df}=3.191$, $\mathrm{P}=0.00 ; \mathrm{F}_{\text {Total life }}=2.033, \mathrm{df}=3.256, \mathrm{P}=0.11 ; \mathrm{F}_{\text {Daily_number_crawlers }}=119.505, \mathrm{df}=3.191, \quad \mathrm{P}=0.00 ;$ $\left.\mathrm{F}_{\text {Total_number_crawlers }}=109.068, \mathrm{df}=3.191, \mathrm{P}=0.00\right)$. 


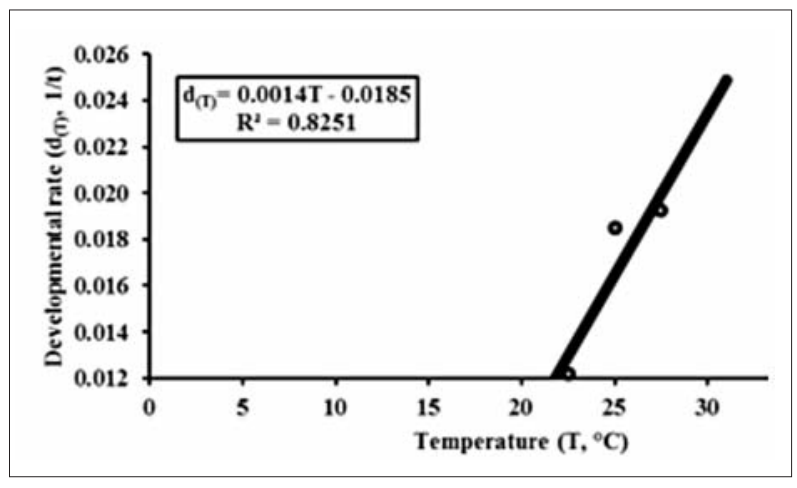

Fig. I - Temperature-dependent development rates of female population in Chrysomphalus dictyospermi at different temperatures. complete a generation (K) was 714.29 degree days. CABIDO-GARCI (1949) reported that the developmental zero of $C$. dictyospermi population was $5.8^{\circ} \mathrm{C}$ in Portugal.

Life table parameters calculated over $C$. dictyospermi populations in different temperature conditions are given in

The longest net productive rate $\left(R_{0}\right)$ of $C$. dictyospermi at $30^{\circ} \mathrm{C}$ was calculated as 70.58 females/female and its gross reproductive rate $(G R R)$ was 88.61 females/female at $30^{\circ} \mathrm{C}$. It was recorded that the longest mean generation rate $\left(T_{0}\right)$ was 102.17 days and longest doubling time $\left(T_{2}\right)$ was 22.62 days at $22.5^{\circ} \mathrm{C}$. Finite rate of increase $(l)$ was determined as 1.03 females/female at $22.5^{\circ} \mathrm{C}$ and was lower when compared to those at $25,27.5$ and $30^{\circ} \mathrm{C}$ (Table 2). Total life time of $C$. dictyospermi was strongly affected by high temperatures, lasted for 82.29 days at $25^{\circ} \mathrm{C}$, while it was 101.91 days at $22.5^{\circ} \mathrm{C}$ (Fig. II).

Table 2 - Intrinsic rate of increase $\left(r_{m}\right)$ were calculated between 0.03-0.06 females/female/day depending on temperature increase.

\begin{tabular}{lcccc}
\hline \hline Parameters & $22.5^{\circ} \mathrm{C}$ & $25^{\circ} \mathrm{C}$ & $27.5^{\circ} \mathrm{C}$ & $30^{\circ} \mathrm{C}$ \\
\hline Intrinsic rate of increase, $\mathrm{r}_{\mathrm{m}}{ }^{*}$ & $0.0306 \pm 0.000014 \mathrm{~d}$ & $0.0586 \pm 0.000018 \mathrm{~b}$ & $0.0475 \pm 0.000025 \mathrm{c}$ & $0.0622 \pm 0.000022 \mathrm{a}$ \\
Net reproduction rate, $\mathrm{R}_{\mathrm{o}}$ & 22.89 & 50.96 & 24.79 & 70.58 \\
Mean generation time, $\mathrm{T}_{\mathrm{o}}$ & 102.17 & 67.04 & 66.21 & 68.49 \\
Gross reproductive rate, $\mathrm{GRR}$ & 32.76 & 66.96 & 33.07 & 88.61 \\
Doubling time, $\mathrm{T}_{2}$ & 22.62 & 11.82 & 14.30 & 11.15 \\
Finite rate of increase, $\lambda$ & 1.03 & 1.06 & 1.05 & 1.06 \\
$\mathbf{N}$ & 73 & 68 & 60 & 59 \\
\hline
\end{tabular}

* Means ( \pm Standard errors) followed by different letters within columns are significantly different (Tukey’s HSD; $\left.\mathrm{P}<0.05 ; \mathrm{F}_{\text {Intrinsic_rate_increase }}=539764.409, \mathrm{df}=3.252, \mathrm{P}=0.00\right)$.

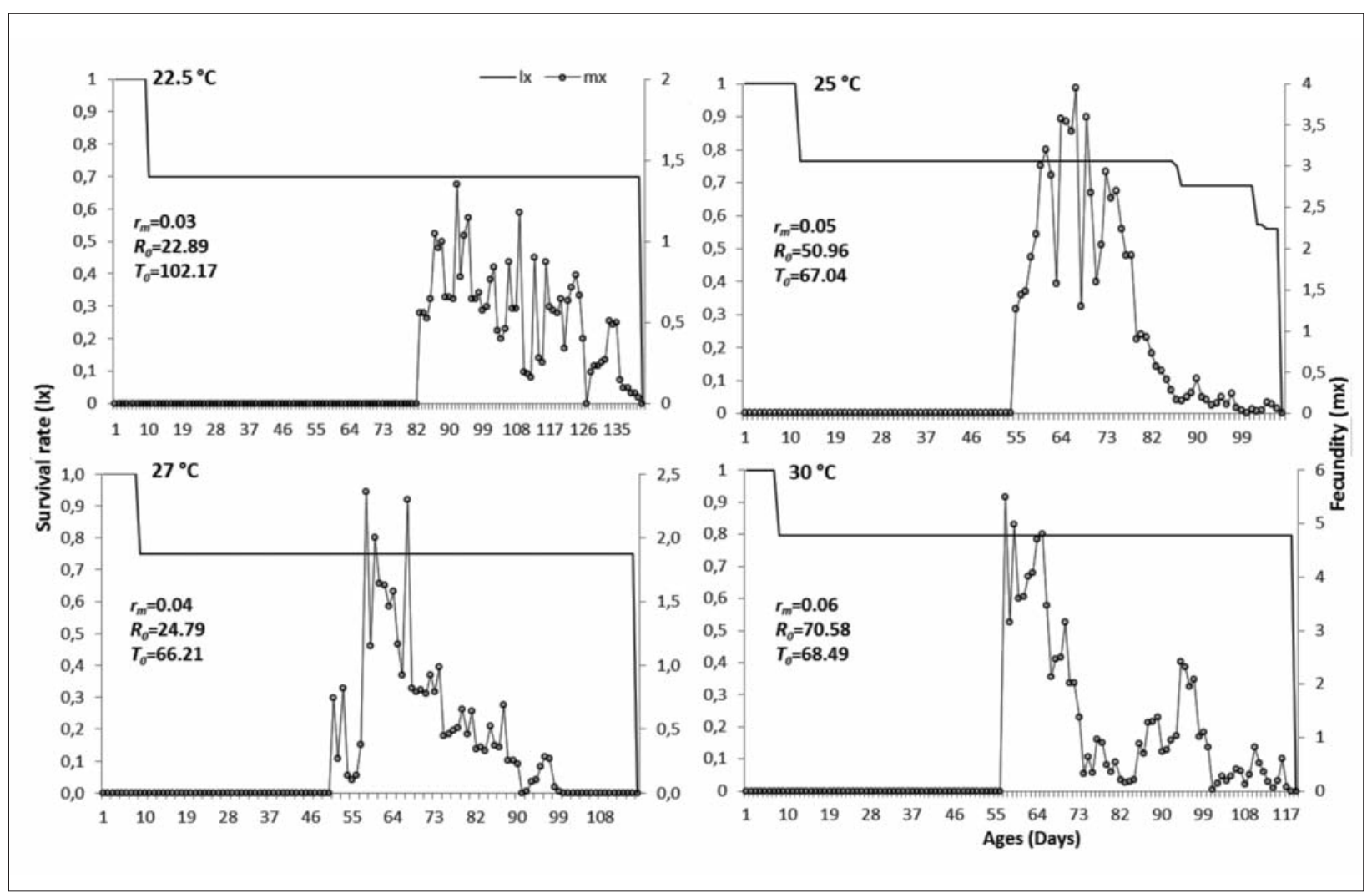

Fig. II - Survival rates $\left(\mathrm{l}_{\mathrm{x}}\right)$, and fecundities $\left(\mathrm{m}_{\mathrm{x}}\right)$ of Chrysomphalus dictyospermi at different temperatures. 
A study on effective temperature requirement of Aspidiotus nerii Bouché (Hemiptera: Diaspididae) by GONZÁLEZ-ZAMORA et al. (2012) reported that the first- and second stage nymphs, and young female individuals require $24.4,11.1$, and 13.2 days, respectively, to complete their developments at $25^{\circ} \mathrm{C}$, but showed no development at $30^{\circ} \mathrm{C}$. However, in the present study $C$. dictyospermi showed development at $30^{\circ} \mathrm{C}$. Thus, it is possible to say that $A$. nerii is more susceptible against seasonal and global temperature rise than $C$. dictyospermi. RAVUIWASA et al. (2012) conducted a two-sex life table study of Aulacaspis yasumatsui Takagi (Hemiptera: Diaspididae), at 20, 23, 25, 28 , and $31^{\circ} \mathrm{C}$; the intrinsic rate of increase $\left(r_{m}\right)$ under these temperatures was $0.06,0.07,0.09,0.10$, and $0.08 \mathrm{~d}^{-1}$, respectively. A. yasumatsui does well at warmer temperatures $\left(25-28^{\circ} \mathrm{C}\right)$; however, lower temperatures adversely affects it performance. In a study of the life cycle of Parlatoria blanchardii (Hemiptera: Diaspididae), the preoviposition period, first-, and second nymph stage periods, and oviposition period were recorded as 6-13, 7-18, 9-26, and 28-59 days, respectively, at $22.5-25.5^{\circ} \mathrm{C}$, under laboratory conditions (ABD EL-RAZZIK, 2000).

GERSON \& HAZAN (1979) reported that oviposition periods of $A$. nerii were $39.70,37.20$, and 33.10 days on potato at 19,24 , and $28^{\circ} \mathrm{C}$; . the total number of crawlers was $91.30,99.70$, and 55.10 crawlers at the same temperatures. HABIB et al. (1969) stated that egg production of Parlatoria oleae (Colvée) (Hemiptera: Diaspididae) also decreased with higher temperatures. According to this study, the egg number of $P$. oleae was 126 , and 105.1 eggs per female at 24 , and $30^{\circ} \mathrm{C}$, respectively. Although insects live in a variety of changing biotic and abiotic factors with different temperature regimes, studies on the effect of temperature can be very useful to understand the population dynamics of various insects. For example, a study by STATHAS et al. (2011) demonstrated the effect of temperature and prey on the development of a predator, Harmonia axyridis (Pallas) (Coleoptera: Coccinellidae). $H$. axyridis has similar degree-day requirements on both preys, Aphis fabae Scopoli and Dysaphis crataegi (Kaltenbach) (Hemiptera: Aphididae) (STATHAS et al., 2011). The development of all immature stages of $H$. axyridis were shorter on $D$. crataegi than on $A$. fabae at most temperatures (STATHAS et al., 2011). The last point is important to predict that the predator can be established in a place. Likewise, another study on the temperaturedependent development of predators, Nephus includens (Kirsch) and N. bisignatus (Boheman) (Coleoptera: Coccinellidae) reared on Planococcus citri (Risso) (Hemiptera: Pseudococcidae) by KonTODIMAs et al. (2004) suggested the linear model as the most efficient method for the description of temperature-dependent development of these predators, and possibly for other coccinellids. The linear equation was indeed very well-fitted to experimental data obtained from the present study, as well. The results of this research proved that different temperatures have an important effect on the biological characteristics of $C$. dictyospermi. The biological characteristics provide population growth rates of an insect (TAZEROUNI \& TALEBI, 2014; FREI et al., 2003) and therefore, understanding them is important when establishing pest management programs. According to the predicted population growth parameters, the optimum temperature for outbreaks of $C$. dictyospermi seems to be $30^{\circ} \mathrm{C}$. Accordingly, our results provide essential information and when this information is used in association with other ecological data, it can be important to predict how population of this pest will be affected by seasonal and global temperature changes. Also, the data can be used to improve pest management programs for $C$. dictyospermi.

\section{ACKNOWLEDGMENTS}

This study was presented as oral presentation at the XIV International Symposium on Scale Insect Studies (ISSIS) which held on 13-16 June 2016 in Catania/Italia.

\section{REFERENCES}

ABD EL-RAZZIK M.E., 2000 - Survey of date palm in North Sinai with special reference to the ecology and biology of the species, Parlatoria blanchardii (Targ.-Tozz) superfamily Coccidea. - M. Sc., Thesis, Faculty of Agriculture. Cairo University, pp. 97.

Alford D.V., 2007 - Pests of Fruit Crops. -Manson Publishing, London, $461 \mathrm{pp}$.

Argyriou L.C., 1990 - Olive. In. Rosen, D. (Eds.). Armored Scale Insects, Their Biology, Natural Enemies and Control. -World Crop Pests, vol 4B. Elsevier, Amsterdam, London, pp. 579-583.

Ben-Dov Y., 2012 - Scale Net, Chrysomphalus. http://www.sel.barc.usda.gov/catalogs/diaspidi/Chrysomp halus-All.htm (accessed 24 April 2012).

BIRCH, L.C., 1948 - The intrinsic rate of natural increase of an insect population. - J. Anim. Ecol, 17: 15-26.

CABIDO-GARCIA R., 1949 - A contribution to the study of the systematics, morphology, biology and ecology of the yellow scale (Chrysomphalus dictyospermi). -Bolletin Jta. Nac. Frutas., 9(3): 374-465.

Campbell A., Frazer B.D., Gilbert N., Gutierez A.P., MACKAUER M., 1974 - Temperature requirements of some some aphids and their parasites. - J. Appl. Ecol, 11: 431438

CHuA T.H., WoOD B.J., 1990 - Other tropical fruit trees and shrubs. In. Rosen, D. (Eds.), Armored scale insects, their biology, natural enemies and control, 4B. Elsevier, New York, pp.543-552.

Chrhaidze L., Yasnosh V., 2001 - The dictyospermum scale Chrysomphalus dictyospermi (Morgan) (Coccinea: Diaspididae), pest of fruit and ornamental plants in the Black Sea coast of Georgia: a review. - Bollettino di Zoologia Agraria e Bachicoltura, 33(3): 495-499.

Danzig E.M., Pellizzari G., 1998 - Diaspididae. In: Kozár F. (Eds.). Catalogue of Palaearctic Coccoidea. Hungarian Academy of Sciences. Budapest, Hungary: Akaprint Nyomdaipari Kft, pp.172-370.

FOLDI I.,2001 - Liste des cochenilles de France (Hemiptera, Coccoidea). [List of scale insects of France (Hemiptera, Coccoidea)]. - Bulletin de la Société Entomologique de France, 106: 303-308

Frei A., Gu H., Bueno J.M., Cardona C., Dorn S., 2003 Antixenosis and antibiosis of common beans to Thrips palmi Karny (Thysanoptera: Thripidae). - J. Econ. Entomol., 96 (5):1577-1584.

Gerson U., Hazan A., 1979 - A biosystematic study of Aspidiotus nerii Bouché (Homoptera: Diaspididae) with the description of one new species. - Journal of Natural History, 13: 275-284.

GILL, R.J., 1997 - The scale insects of California: Part 3. The armored scales (Homoptera:Diaspididae). California Department of Food and Agriculture, Sacramento, CA. 307 pp. 
GonZÁlez-Zamora J.E., Castillo M.L., Avilla C., 2012 Assessment of life history parameters of Aspidiotus nerii (Hemiptera: Diaspididae) to improve the mass rearing of Aphytis melinus (Hymenoptera: Aphelinidae). - Biocontrol Science and Technology, 22(7): 791-801.

Habib A., Salama H.S., Amin A., 1969 - The biology of the plum scale, Parlatoria oleae (Colvée) (Coccoidea: Diaspididae). - Bull. Soc. Ent. Egypt, 53: 283-297.

KaIRo, M. T. K., Murphy, S. T., 1995 - The life history of Rodolia iceryae Janson (Coleoptera:Coccinellidae) and the potential for use in innoculative releases against Icerya pattersoni Newstead (Homoptera: Margarodidae) on coffee. - J. Appl. Entomo., 119: 487-491.

Kontodimas D.C., Eliopoulos P.A., Stathas G.J., ECONOMOU L.P., 2004 - Comparative temperaturedependent development of Nephus includens (Kirsch) and Nephus bisignatus (Boheman) (Coleoptera: Coccinellidae), preying on Planococcus citri (Risso) (Homoptera: Pseudococcidae): Evaluation of a linear and various non-linear models using specific criteria. Environmental Entomology, 33 (1): 1-11.

Longo S., Marotta S., Pellizzari G., Russo A., Tranfaglia A., 1995 - An annotated list of the scale insects (Homoptera: Coccoidea) of Italy. - Isr. J. Entomol, 29: 113-130

Meyer J.S., C.G., Ingersoll L.L., McDonald, Boyce M.S., 1986 - Estimating uncertainty in population growth rates: Jackknife vs. Bootstrap techniques. -Ecology, 67: 1156-1166.

ÖZGÖKÇE M. S., ATLIHAN R., 2004 - Biological features and life table parameters of mealyplum aphid, Hyalopterus pruni on different apricot cultivars. - Phytoparasitica, 33 (1): 7-14.

Ravuiwasa K.T., Tan C.W., BezirganoĞLu İ., Hwang S.Y., 2012 - Temperature-dependent demography of Aula caspis yasumatsui (Hemiptera: Diaspididae). - J. Econ. Entomol, 105 (5), 1581-1590.

Williams D.J., WATSON G.W., 1988 - The scale insects of the tropical south Pacific Region: Part 1, The armored scales (Diaspididae). - CAB International Institute of Entomology; London, $290 \mathrm{p}$.

Stathas G.J., Kontodimas D.C., Karamaouna F., KAMPOURIS S., 2011 - Thermal requirements and effect of temperature and prey on the development of the predator Harmonia axyridis. - Environmental Entomology, 40 (6): 1541-1545.

USDA, 2014 - ScaleNet database. USDA project. http://www.sel.barc.usda.gov/scalenet/scalenet.html (Accessed 24 April 2014).

TAZEROUni Z., TALEBI A.A., 2014 - Temperature-dependent life history of Sipha maydis (Hemiptera: Aphididae) on wheat. -J. Plant Prot. Res., 54 (4): 374-382. 
